\title{
Exam period, stress, and substance use/abuse in medical students: A multi-school study in southern Brazil
}

\author{
Angelo Ap de Barros Jr ${ }^{1}$, Ulisses $\mathrm{H}_{\text {de Souza }}{ }^{1}$, Tânia Zaleski ${ }^{2}$, Luiza Tatiana Forte ${ }^{3}$ and Francelise B Cavassin ${ }^{4 *}$ \\ ${ }^{1}$ Medical School Undergraduate Program, Faculdades Pequeno Príncipe (FPP), Curitiba, Paraná State, Brazil \\ ${ }^{2}$ Medical Sciences, Faculdades Pequeno Príncipe (FPP), Curitiba, Paraná State, Brazil; Faculty of Biological Sciences, Universidade Estadual do Paraná (UNESPAR), \\ Paranaguá, Brazil and Post Graduate Program of National Network's in Education, Universidade Federal do Paraná (UFPR), Brazil \\ ${ }^{3}$ Extension Program Director of Faculdades Pequeno Príncipe (FPP), Curitiba, Paraná State, Brazil \\ ${ }^{4}$ Medical Sciences, Faculdades Pequeno Príncipe (FPP), Curitiba, Paraná State, Brazil, and Clinical Research Coordinator at Universidade Federal do Paraná \\ (UFPR), Curitiba, Paraná State, Brazil
}

\begin{abstract}
Purpose. Given the high incidence of psychological problems related to the demand generated by medical graduation the search for methods of stress relief occurs in several ways, one of which is the consumption of substances. This study was designed to determine the use of substances as a stress relief factor during the exam period among medical students in a city of southern Brazil.

Method. Electronic survey was sent to medical students from five medical Higher Education Institutions at a city of southern Brazil during the second semester of 2019. Completing the survey was voluntary and anonymous. The questionnaire addressed the participants' stress during the school term and exam, the consumption or abuse of nine substances and the reasons that led to it.

Results. For the research, were validated 558 participants $(\mathrm{CI}=95 \% ; \alpha=3.88 \%)$. Most respondents were female and between 18 and 24 years old. For $293(52.5 \%)$, stress was constantly present during the year with an increase to $516(92 \%)$ during the exam period. The most consumed substances were alcohol, marijuana and tobacco, however, alcohol $(n=267,54 \%)$, tobacco $(n=67,31 \%)$ and benzodiazepines $(n=26,25 \%)$ were the most frequently consumed. All substances had an expressed increase in use after individuals entered higher education. Attention to inhalants, which reached $600 \%$ when compared to their consumption reported before college. Specifically, during the exam, all substances had an increase in frequency and amount of use, with emphasis on benzodiazepines $(P=0.02)$ and marijuana $(P$ $=0.02$ ). In the users' perception, the main reasons listed were recreation, socialization, and stress relief.
\end{abstract}

Conclusions. Higher education involves a period of adjustment and new experiences, with a clear change in the pattern of substance use. New perspectives for the development of prevention strategies are urgent in this context.

\section{Introduction}

In 1959, the first definition of stress had a biological point of view stating that it is an inherent element in every disease that can lead to structural and chemical changes and that can be perceived and measured in the human body. Later, in the 90s, this definition gained a more comprehensive view, considering the psychological, social, and physical spheres, saying that stress involves multiple reactions and stimuli, leading to deleterious effects due to the body's imbalance [1].

About 970 million people worldwide had some mental disorder in 2017, being anxiety the most prevalent condition, affecting 301 million people [2]. In Brazilian medical students, the stress prevalence reaches 50\%. The most related factors to this index are the first year of graduation, low family income, female sex, dissatisfaction with the course, and escape or avoidance as a coping strategy [3]. Furthermore, suicide rates among medical students are higher than in the general population and other academic groups, reaching rates close to $54 \%$ of suicidal ideation. The causes pointed out include psychological distress related to work and study and the higher incidence of psychiatric disorders, such as depression [4-6]. Rotenstein, et al. [7] in a metaanalysis, found that depression or depressive symptoms occur in $27 \%$ of the medical students. In Brazil, this index is even higher, reaching $31 \%$ of the same population [3].
Given the high incidence of psychological problems related to the demand generated by medical graduation, the search for forms of stress relief occurs in several ways, one of which is the consumption and abusive use of licit and illicit substances (Supplementary Material). The risk factors to substance use during college include low family interaction, few moments of leisure, and factors of the graduation itself, such as the extensive workload, tiredness, the concern with academic performance, and the experience of human suffering and death [8]. Furthermore, stress and the post-exam period are two of the main reasons for alcohol use among academics and its frequency seems to increase with the progress of the course. For Pacheco, et al. [3] the index related to anxiety (33\%), poor sleep quality (51\%), daytime sleepiness (46.1\%), and substance abuse, like alcohol (33\%), is worrisome.

Considering the evident burden of academic stress during the medical school trajectory, we proposed to determine the use of

${ }^{\star}$ Correspondence to: Francelise Bridi Cavassin, 333, Iguaçu Avenue. CEP: 80230-020. Curitiba-PR, Brazil, Tel: +55 41 996961251; E-mail: francelise. cavassin@professor.fpp.edu.br

Key words: academic stress, exam's period, medical student, stress relief, substance use Received: May 14, 2021; Accepted: June 11, 2021; Published: June 14, 2021 
substances as a stress relief factor during the exam period among medical students in a city of southern Brazil.

\section{Method}

This is a cross-sectional report research which was carried out through the application of a semi-structured online questionnaire. The target population consisted of medical students from Curitiba, capital of the State of Paraná, in the southern region of Brazil. The city contains 132 Higher Education Institutions (HEI) recognized by the Brazilian Ministry of Education (MEC), but only five offer the medical course. These five institutions were part of the research.

According to the last updated database (e-MEC), considering that all vacancies were occupied, the probable number of medical students during data collection period was $4504[9,10]$. The minimum sample calculated for this study, with 5\% sampling error and $95 \%$ confidence level, was 355 students. Academics enrolled in any period of the course (basic, clinical and internship) answered the questionnaire. Completing the survey was voluntary and anonymous. There was no impediment to participation regarding gender, ethnicity or color. However, participants under the age of 18 were not considered.

\section{Data collection and analysis}

We developed an anonymous questionnaire containing 65 items and incorporating mostly closed-ended, multiple-choice questions, through the Google forms online platform. All students received the survey link via e-mail or by groups of transmission via WhatsApp. Since all academics of legal age from the five HEI were targeted for the study, their identities or responses were not compromised by receiving the invitation message. In addition, the responses to the questionnaire were linked to a restricted email, preserving exclusive access to the three of us, thus ensuring data confidentiality.

The data collection period was from 09/02/2019 to 12/31/2019. After that, we stored all information in a Microsoft Excel ${ }^{\oplus}$ spreadsheet to proceed with the analyses. The frequencies were tested using the chisquare and Fisher's exact test, through IBM SPSS Statistics for Windows, Version 22.0 (IBM Corp, Armonk, New York), with a significance level of $5 \%$.

\section{Ethical approval}

This study was approved by the Ethics and Research Committee of Faculdades Pequeno Príncipe (FPP) under CAAE 17493319.7.0000.5580 and opinion number $3,498,079$.

\section{Results}

Of the 565 participants who accessed the questionnaire, 558 were over 18 years old. This total of responses allowed a $95 \%$ confidence index with a of $3.88 \%$.

The profile of the studied population and its relationship with stress could be established and, through the frequency test, a significant difference between genders, inside the 18 to 24 years old age group was perceived $(\mathrm{p}<0.05)$. A total of 444 participants $(80 \%)$ considered that academic stress worsens quality of life or academic performance outside the exam period, with an increase to 525 responses (94\%) during this time. There were no fields with incomplete answers (Table 1).

To analyze substance use/abuse, we included questions about alcohol, tobacco, marijuana, cocaine, amphetamines, hallucinogens, inhalants, opioids, and benzodiazepines (BZD).
Table 1. Profile of medical students and their perception of stress by absolute (n) and relative $(\%)$ frequency

\begin{tabular}{|c|c|}
\hline Participants/ Form questions & $\mathrm{n}(\%), 558(100)$ \\
\hline \multicolumn{2}{|l|}{ Gender } \\
\hline Male & $182(32.6)$ \\
\hline Female & $376(67.4)$ \\
\hline \multicolumn{2}{|l|}{ Age group } \\
\hline 18 to 24 years old & $445(79.7)^{*}$ \\
\hline 25 to 29 years old & $86(15.4)$ \\
\hline 30 years or older & $27(4.8)$ \\
\hline \multicolumn{2}{|c|}{$\begin{array}{l}\text { Do you consider yourself stressed out of } \\
\text { the exam period? }\end{array}$} \\
\hline Yes & $293(52.5)$ \\
\hline No & $265(47.5)$ \\
\hline \multicolumn{2}{|c|}{$\begin{array}{l}\text { Do you consider that stress worsens your } \\
\text { life quality and/or academic performance } \\
\text { out of the exam period? }\end{array}$} \\
\hline Yes & $444(79.6)$ \\
\hline No & $114(20.4)$ \\
\hline \multicolumn{2}{|c|}{$\begin{array}{l}\text { Do you consider yourself stressed during } \\
\text { the exam period? }\end{array}$} \\
\hline Yes & $512(91.8)$ \\
\hline No & $46(8.2)$ \\
\hline \multicolumn{2}{|c|}{$\begin{array}{l}\text { Do you consider yourself more stressed in } \\
\text { the exam period than out of it? }\end{array}$} \\
\hline Yes & $516(92.5)$ \\
\hline No & $42(7.5)$ \\
\hline \multicolumn{2}{|c|}{$\begin{array}{l}\text { Do you consider that stress worsens your } \\
\text { life quality and/or academic performance } \\
\text { during the exam period? }\end{array}$} \\
\hline Yes & $525(94.1)$ \\
\hline No & $33(5.9)$ \\
\hline
\end{tabular}

$\mathrm{n}=$ total number of participants; * Significant difference between genders inside the 18 to 24 years old age group $(\mathrm{p}=0.04)$

Source: Elaborated by the authors

Alcohol was the most consumed substance, with 495 affirmative responses. There was also an increase in alcohol consumption after joining the HEI. When we analyzed the use during the exam period, 39 participants (8\%) related an increase in the frequency and $35(7 \%)$ in the amount of use.

Marijuana was the second most cited substance, with 266 affirmative responses. As with alcohol, there was a considerable increase in the number of individuals who started marijuana after entering college, as well as in frequency $(\mathrm{n}=23,8.5 \%)$ and in the amount of use $(6.4 \%, \mathrm{n}=$ 17) in exam period.

Tobacco occupied the third position and again it was possible to verify that, during the exam period, its frequency and amount of use was increased by 65 (30.9\%) and 64 (29.6\%) participants, respectively.

When we analyzed the reasons that led participants to use substances, the main option reported was 'recreation' in six of the nine groups of substances. 'Stress relief' was cited as the second reason in two of them and as the third in six other options.

The substances that were used more often were alcohol, tobacco and BZDs. Among the participants who reported alcohol use, 267 (54\%) said they consume more than once a month. For tobacco and BZDs, $67(31 \%)$ and $26(25 \%)$ said the same, respectively. The substances with the lowest frequency of use, at most once a month, were inhalants $(\mathrm{n}=$ $124,99.2 \%)$, opioids $(n=44,97.7 \%)$ and hallucinogens $(n=83,97.6 \%)$ (Table 2). 
Table 2. Absolute (n) and relative frequency (\%) of substance use/abuse by medical students in relation to the variables covered in the online questionnaire.

\begin{tabular}{|c|c|c|c|c|c|c|c|c|c|}
\hline Substance & $\begin{array}{c}\text { Alcohol } \\
(\mathrm{n}=495)\end{array}$ & Tobacco $(n=216)$ & $\begin{array}{c}\text { Marijuana } \\
(n=266)\end{array}$ & Cocaine $(n=35)$ & $\begin{array}{l}\text { Amphetamines } \\
(n=160)\end{array}$ & $\begin{array}{l}\text { Hallucinogens } \\
\qquad(\mathrm{n}=\mathbf{8 5})\end{array}$ & $\begin{array}{c}\text { Inhalants } \\
(n=125)\end{array}$ & Opioids (n=45) & BZDs* $(n=105)$ \\
\hline \multicolumn{10}{|l|}{ Reasons of use } \\
\hline Stress Relief & $\begin{array}{c}151 \\
(30.50 \%)\end{array}$ & $\begin{array}{c}95 \\
(43.98 \%)\end{array}$ & $\begin{array}{c}116 \\
(43.61 \%)\end{array}$ & $\begin{array}{c}5 \\
(14.29 \%)\end{array}$ & $\begin{array}{c}13 \\
(8.13 \%)\end{array}$ & $\begin{array}{c}11 \\
(12.94 \%)\end{array}$ & $\begin{array}{c}11 \\
(8.80 \%)\end{array}$ & $\begin{array}{c}19 \\
(42.22 \%)\end{array}$ & $\begin{array}{c}57 \\
(54.29 \%)\end{array}$ \\
\hline Recreation & $\begin{array}{c}387 \\
(78.18 \%)\end{array}$ & $\begin{array}{c}109 \\
(50.46 \%)\end{array}$ & $\begin{array}{c}210 \\
(78.95 \%)\end{array}$ & $\begin{array}{c}27 \\
(77.14 \%)\end{array}$ & $\begin{array}{c}87 \\
(54.38 \%)\end{array}$ & $\begin{array}{c}71 \\
(83.53 \%)\end{array}$ & $\begin{array}{c}116 \\
(92.80 \%)\end{array}$ & $\begin{array}{c}9 \\
(20.00 \%)\end{array}$ & $\begin{array}{c}5 \\
(4.76 \%)\end{array}$ \\
\hline Socialization & $\begin{array}{c}384 \\
(77.58 \%)\end{array}$ & $\begin{array}{c}111 \\
(51.39 \%)\end{array}$ & $\begin{array}{c}135 \\
(50.75 \%)\end{array}$ & $\begin{array}{c}12 \\
(34.29 \%)\end{array}$ & $\begin{array}{c}42 \\
(26.25 \%)\end{array}$ & $\begin{array}{c}28 \\
(32.94 \%)\end{array}$ & $\begin{array}{c}55 \\
(44.00 \%)\end{array}$ & $\begin{array}{c}2 \\
(4.44 \%)\end{array}$ & $\begin{array}{c}1 \\
(0.95 \%)\end{array}$ \\
\hline $\begin{array}{l}\text { Concentration } \\
\text { Improvement }\end{array}$ & $\begin{array}{c}7 \\
(1.41 \%)\end{array}$ & $\begin{array}{c}34 \\
(15.74 \%)\end{array}$ & $\begin{array}{c}4 \\
(1.50 \%)\end{array}$ & $\begin{array}{c}5 \\
(14.29 \%)\end{array}$ & $\begin{array}{c}66 \\
(41.25 \%)\end{array}$ & $\begin{array}{c}1 \\
(1.18 \%)\end{array}$ & $\begin{array}{c}0 \\
(0.00 \%)\end{array}$ & $\begin{array}{c}1 \\
(2.22 \%)\end{array}$ & $\begin{array}{c}5 \\
(4.76 \%)\end{array}$ \\
\hline $\begin{array}{l}\text { Sleepiness } \\
\text { Induction or } \\
\text { Maintenance }\end{array}$ & $\begin{array}{c}34 \\
(6.87 \%)\end{array}$ & $\begin{array}{c}9 \\
(4.17 \%)\end{array}$ & $\begin{array}{c}56 \\
(21.05 \%)\end{array}$ & $\begin{array}{c}0 \\
(0.00 \%)\end{array}$ & $\begin{array}{c}3 \\
(1.88 \%)\end{array}$ & $\begin{array}{c}0 \\
(0.00 \%)\end{array}$ & $\begin{array}{c}1 \\
(0.80 \%)\end{array}$ & $\begin{array}{c}7 \\
(15.56 \%)\end{array}$ & $\begin{array}{c}69 \\
(65.71 \%)\end{array}$ \\
\hline Others & $\begin{array}{c}18 \\
(3.64 \%)\end{array}$ & $\begin{array}{c}20 \\
(9.26 \%)\end{array}$ & $\begin{array}{c}15 \\
(5.64 \%)\end{array}$ & $\begin{array}{c}5 \\
(14.29 \%)\end{array}$ & $\begin{array}{c}13 \\
(8.13 \%)\end{array}$ & $\begin{array}{c}6 \\
(7.06 \%)\end{array}$ & $\begin{array}{c}1 \\
(0.80 \%)\end{array}$ & $\begin{array}{c}22 \\
(48.89 \%)\end{array}$ & $\begin{array}{c}22 \\
(20.95 \%)\end{array}$ \\
\hline \multicolumn{10}{|c|}{ Frequency (periodicity) } \\
\hline Always & $\begin{array}{c}46 \\
(9.29 \%)\end{array}$ & $\begin{array}{c}36 \\
(16.67 \%)\end{array}$ & $\begin{array}{c}25 \\
(9.40 \%)\end{array}$ & $\begin{array}{c}1 \\
(2.86 \%)\end{array}$ & $\begin{array}{c}17 \\
(10.63 \%)\end{array}$ & $\begin{array}{c}1 \\
(1.18 \%)\end{array}$ & $\begin{array}{c}0 \\
(0.00 \%)\end{array}$ & $\begin{array}{c}0 \\
(0.00 \%)\end{array}$ & $\begin{array}{c}10 \\
(9.52 \%)\end{array}$ \\
\hline $\begin{array}{l}\text { Often (Maximum } \\
\text { once a week) }\end{array}$ & $\begin{array}{c}221 \\
(44.65 \%)\end{array}$ & $\begin{array}{c}31 \\
(14.35 \%)\end{array}$ & $\begin{array}{c}26 \\
(9.77 \%)\end{array}$ & $\begin{array}{c}1 \\
(2.86 \%)\end{array}$ & $\begin{array}{c}15 \\
(9.38 \%)\end{array}$ & $\begin{array}{c}1 \\
(1.18 \%)\end{array}$ & $\begin{array}{c}1 \\
(0.80 \%)\end{array}$ & $\begin{array}{c}1 \\
(2.22 \%)\end{array}$ & $\begin{array}{c}16 \\
(15.24 \%)\end{array}$ \\
\hline $\begin{array}{l}\text { Sometimes } \\
\text { (Maximum once } \\
\text { a month) }\end{array}$ & $\begin{array}{c}163 \\
(32.93 \%)\end{array}$ & $\begin{array}{c}38 \\
(17.59 \%)\end{array}$ & $\begin{array}{c}63 \\
(23.68 \%)\end{array}$ & $\begin{array}{c}3 \\
(8.57 \%)\end{array}$ & $\begin{array}{c}37 \\
(23.13 \%)\end{array}$ & $\begin{array}{c}9 \\
(10.59 \%)\end{array}$ & $\begin{array}{c}29 \\
(23.20 \%)\end{array}$ & $\begin{array}{c}6 \\
(13.33 \%)\end{array}$ & $\begin{array}{c}27 \\
(25.71 \%)\end{array}$ \\
\hline $\begin{array}{l}\text { Rarely } \\
\text { (Maximum of } \\
\text { four times a year) }\end{array}$ & $\begin{array}{c}56 \\
(11.31 \%)\end{array}$ & $\begin{array}{c}77 \\
(35.65 \%)\end{array}$ & $\begin{array}{c}118 \\
(44.36 \%)\end{array}$ & $\begin{array}{c}21 \\
(60.00 \%)\end{array}$ & $\begin{array}{c}74 \\
(46.25 \%)\end{array}$ & $\begin{array}{c}54 \\
(63.53 \%)\end{array}$ & $\begin{array}{c}88 \\
(70.40 \%)\end{array}$ & $\begin{array}{c}29 \\
(64.44 \%)\end{array}$ & $\begin{array}{c}42 \\
(40.00 \%)\end{array}$ \\
\hline Never & $\begin{array}{c}9 \\
(1.82 \%)\end{array}$ & $\begin{array}{c}34 \\
(15.74 \%)\end{array}$ & $\begin{array}{c}34 \\
(12.78 \%)\end{array}$ & $\begin{array}{c}9 \\
(25.71 \%)\end{array}$ & $\begin{array}{c}17 \\
(10.63 \%)\end{array}$ & $\begin{array}{c}20 \\
(23.53 \%)\end{array}$ & $\begin{array}{c}7 \\
(5.60 \%)\end{array}$ & $\begin{array}{c}9 \\
(20.00 \%)\end{array}$ & $\begin{array}{c}10 \\
(9.52 \%)\end{array}$ \\
\hline \multicolumn{10}{|c|}{ Frequency (occasion) } \\
\hline Last week & $\begin{array}{c}275 \\
(55.56 \%)\end{array}$ & $\begin{array}{c}64 \\
(29.63 \%)\end{array}$ & $\begin{array}{c}71 \\
(26.69 \%)\end{array}$ & $\begin{array}{c}4 \\
(11.43 \%)\end{array}$ & $\begin{array}{c}30 \\
(18.75 \%)\end{array}$ & $\begin{array}{c}3 \\
(3.53 \%)\end{array}$ & $\begin{array}{c}7 \\
(5.60 \%)\end{array}$ & $\begin{array}{c}3 \\
(6.67 \%)\end{array}$ & $\begin{array}{c}20 \\
(19.05 \%)\end{array}$ \\
\hline Last month & $\begin{array}{c}321 \\
(64.85 \%)\end{array}$ & $\begin{array}{c}85 \\
(39.35 \%)\end{array}$ & $\begin{array}{c}106 \\
(39.85 \%)\end{array}$ & $\begin{array}{c}7 \\
(20.00 \%)\end{array}$ & $\begin{array}{c}49 \\
(30.63 \%)\end{array}$ & $\begin{array}{c}13 \\
(15.29 \%)\end{array}$ & $\begin{array}{c}24 \\
(19.20 \%)\end{array}$ & $\begin{array}{c}4 \\
(8.89 \%)\end{array}$ & $\begin{array}{c}34 \\
(32.38 \%)\end{array}$ \\
\hline Last year & $\begin{array}{c}294 \\
(59.39 \%)\end{array}$ & $\begin{array}{c}112 \\
(51.85 \%)\end{array}$ & $\begin{array}{c}136 \\
(51.13 \%)\end{array}$ & $\begin{array}{c}10 \\
(28.57 \%)\end{array}$ & $\begin{array}{c}76 \\
(47.50 \%)\end{array}$ & $\begin{array}{c}30 \\
(35.29 \%)\end{array}$ & $\begin{array}{c}58 \\
(46.40 \%)\end{array}$ & $\begin{array}{c}10 \\
(22.22 \%)\end{array}$ & $\begin{array}{c}33 \\
(31.43 \%)\end{array}$ \\
\hline During college & $\begin{array}{c}402 \\
(81.21 \%)\end{array}$ & $\begin{array}{c}170 \\
(78.70 \%)\end{array}$ & $\begin{array}{c}216 \\
(81.20 \%)\end{array}$ & $\begin{array}{c}22 \\
(62.86 \%)\end{array}$ & $\begin{array}{c}131 \\
(81.88 \%)\end{array}$ & $\begin{array}{c}65 \\
(76.47 \%)\end{array}$ & $\begin{array}{c}112 \\
(89.60 \%)\end{array}$ & $\begin{array}{c}34 \\
(75.56 \%)\end{array}$ & $\begin{array}{c}89 \\
(84.76 \%)\end{array}$ \\
\hline $\begin{array}{l}\text { Before entering } \\
\text { college }\end{array}$ & $\begin{array}{c}341 \\
(68.89 \%)\end{array}$ & $\begin{array}{c}126 \\
(58.33 \%)\end{array}$ & $\begin{array}{c}156 \\
(58.65 \%)\end{array}$ & $\begin{array}{c}16 \\
(45.71 \%)\end{array}$ & $\begin{array}{c}66 \\
(41.25 \%)\end{array}$ & $\begin{array}{c}41 \\
(48.24 \%)\end{array}$ & $\begin{array}{c}16 \\
(12.80 \%)\end{array}$ & $\begin{array}{c}19 \\
(42.22 \%)\end{array}$ & $\begin{array}{c}43 \\
(40.95 \%)\end{array}$ \\
\hline \multicolumn{10}{|c|}{ Does the frequency of use increase during the exam period? } \\
\hline Yes & $\begin{array}{c}39 \\
(7.88 \%)\end{array}$ & \begin{tabular}{|c|}
65 \\
$(30.09 \%)$ \\
\end{tabular} & $\begin{array}{c}23 \\
(8.65 \%)\end{array}$ & $\begin{array}{c}4 \\
(11.43 \%)\end{array}$ & $\begin{array}{c}48 \\
(30.00 \%)\end{array}$ & $\begin{array}{c}1 \\
(1.18 \%)\end{array}$ & $\begin{array}{c}2 \\
(1.60 \%)\end{array}$ & $\begin{array}{c}8 \\
(17.78 \%)\end{array}$ & $\begin{array}{c}49 \\
(46.67 \%)\end{array}$ \\
\hline \multicolumn{10}{|c|}{ Does the amount of use increase during the exam period? } \\
\hline Yes & $\begin{array}{c}35 \\
(7.07 \%)\end{array}$ & \begin{tabular}{|c|}
64 \\
$(29.63 \%)$ \\
\end{tabular} & $\begin{array}{c}17 \\
(6.39 \%)\end{array}$ & $\begin{array}{c}4 \\
(11.43 \%)\end{array}$ & $\begin{array}{c}41 \\
(25.63 \%)\end{array}$ & $\begin{array}{c}1 \\
(1.18 \%)\end{array}$ & $\begin{array}{c}2 \\
(1.60 \%)\end{array}$ & $\begin{array}{c}7 \\
(15.56 \%)\end{array}$ & $\begin{array}{c}40 \\
(38.10 \%)\end{array}$ \\
\hline
\end{tabular}

* BZDs $=$ benzodiazepines

Another important aspect concerns the change in consumption habits after the student's entry into higher education, since all substances presented a greater number of participants reporting their use during college compared to before they entered. Inhalants were the group of substances with the highest percentage increase in this regard, equivalent to $600 \%$. The second and third largest increases were BZDs (107\%) and amphetamines (98.5\%) (Graph 1).

Finally, we show that, numerically, there was an increase in the use of all substances during the exam period, both in frequency and amount of use. The greatest variations were observed in tobacco, with an increase of 60 reports in amount of use and 62 in frequency during exam. The smallest, however, was observed in the group of hallucinogens, where only one participant reported an increase in both aspects. There were statistically significant variations in the frequency of use of BZDs and the amount of use of marijuana (Table 3).

\section{Discussion}

From the results obtained, we can state that, in the perception of medical students, there is an increase in the frequency and amount of substance use during the exam period, since all nine groups of substances had a higher rate of use in relation to the previous period. In addition, stress was listed as a key factor in this increase. Even though the participants belong to a study program in the health area and, therefore, being aware of the potential damage that these substances offer, they were perfectly able to define and justify the reasons for their use. In this sense, the analysis allowed us to compare our data with national and international studies. However, the scarcity of publications available on the use of substances specifically during the exam period did not allow for further comparisons.

\section{Substance use profile among medical students}

The three substances most consumed by participants were alcohol, marijuana and tobacco. Ayala, et al. [11] in 2017, also observed a similar 
Table 3. Proportion of frequency and amount of use among substances and their use related to stress during the exam period

\begin{tabular}{|c|c|c|c|c|c|c|c|c|c|c|}
\hline \multirow{2}{*}{ Substances } & \multicolumn{2}{|c|}{ Total } & \multicolumn{2}{|c|}{ Exam stress } & \multicolumn{3}{|c|}{$\uparrow$ Use frequency } & \multicolumn{3}{|c|}{$\uparrow$ Amount use } \\
\hline & $\mathrm{n}$ & $\%$ & $\mathrm{n}$ & $\%$ & $\mathrm{n}$ & $\%$ & $\mathrm{p}^{*}$ & $\mathrm{n}$ & $\%$ & $\mathrm{p}^{*}$ \\
\hline Alcohol & 495 & 88.71 & 456 & 92.12 & 37 & 8.11 & - & 33 & 7.24 & - \\
\hline Tobacco & 216 & 38.71 & 199 & 92.13 & 62 & 31.16 & - & 60 & 30.15 & - \\
\hline Marijuana & 266 & 47.67 & 247 & 92.86 & 19 & 7.69 & - & 13 & 5.26 & $0.024^{\dagger}$ \\
\hline Cocaine & 35 & 6.27 & 30 & 85.71 & 4 & 13.33 & - & 4 & 13.33 & - \\
\hline Amphetamines & 160 & 28.67 & 145 & 90.63 & 44 & 30.34 & - & 37 & 25.52 & - \\
\hline Hallucinogens & 85 & 15.23 & 76 & 89.41 & 1 & 1.32 & - & 1 & 1.32 & - \\
\hline Inhalants & 125 & 22.4 & 111 & 88.8 & 2 & 1.8 & - & 2 & 1.8 & - \\
\hline Opioids & 45 & 8.06 & 38 & 84.44 & 8 & 21.05 & - & 7 & 18.42 & - \\
\hline Benzodiazepines & 105 & 18.82 & 95 & 90.48 & 48 & 50.53 & $0.018^{\dagger}$ & 39 & 41.05 & - \\
\hline
\end{tabular}

* Chi-square test; $\dagger$ Fisher's exact test

use habit in the United States. When considering the consumption of these same substances, alcohol presented an even more significant profile, with $781(91.3 \%)$ responses affirmative to its use in the year before the data collection. Another research, in United Kingdom, also pointed out that the same three substances were among the most used, with alcohol in first place, but followed by tobacco and then, marijuana [12]. A review, with worldwide data, listed alcohol and tobacco as the licit drugs and, marijuana, as the illicit one, most used among medical students [8]. The variation in the second general position of use between tobacco and marijuana is, probably, justified by the students' awareness of the harm caused by tobacco in long-term use. In this same study, the Brazilian pattern of use had this order: alcohol, tobacco and marijuana.

In 2007, a study conducted in southern Brazil, led by Boniatti, et al. [13] found that alcohol, tobacco and marijuana had 170 (92.9\%), 56 (30.6\%) and 25 (13.7\%) affirmative responses for their use, respectively. We assume that this 'more distributed' percentage observed in our study is justified by the greater accessibility to drugs nowadays by the students. Anyway, the ranking of most used substances remains constant, among the three already mentioned, throughout the literature.

It is remarkable the number of research reporting substance use like a common practice during college. When compared to the same age group, young adults enrolled in a university course had higher rates of substance use disorder and misuse of prescription drugs when it comes, mainly, to stimulants, like amphetamines, whose group is related like an “academic anabolic steroid" [14,15]. Nevertheless, we found an increase of $98.5 \%$ in amphetamine use after entering medical school, being the third largest variation among the groups evaluated.

In 2018, Bogowicz, et al. [12] also related the substance abuse like a common practice between the academical population, mainly alcohol. However, according to the authors, medical students show a lower alcohol consumption profile when in comparison with law students, which corroborates our data when we perceive in alcohol the smallest increase among all substances after entering college (18\%). Oliveira, et al. [16] also reported a notable increase in use within medical school, reaching rates 2.3 times higher among this population group, when compared to the general population. The main increases cited by the authors were perceived in inhalants, amphetamines and hallucinogens. In our study, the three major percentual increases found in use after entering college were, respectively, in inhalants (600\%), BZDs (107\%) and amphetamines (98.5\%).

\section{Risk factors and reasons for substance use during the exam period}

Several authors agree that college is a period of changes and new experiences in academic life. The student experiments social freedom, relates more within a team and the new challenges to comprehend the chosen area led to a scenario with higher personal and family demands, often generating phases that include emotional wear and stress $[3,4,17,18]$. This stress is perceived by medical students, as seen in the 293 participants $(52.5 \%)$ that related to feel normally stressed during all the academic periods. In Brazil, a research conducted in Minas Gerais revealed slightly lower rates of stress $(n=358,47.1 \%)$, while, internationally, Almojali, et al. [20] found that 140 (53\%) medical students recognized themselves as being stressed, which approaches our value. In a survey involving 138 Brazilian students, 109 participants (79\%) considered themselves stressed, with 85 (78\%) in the resistance phase and $23(22 \%)$ in the exhaustion phase, demonstrating the high prevalence and severity of the situation [19,21].

In our study, 516 participants (93\%) consider themselves more stressed in the exam period than in other ones, and 525 (94\%) considered that the exam period leads to a lower life quality and/or academic performance. This data reinforces the idea that this phase is a stressor for students, which opens the possibility for the consumption of different substances as a relief factor. Guraya, et al. [22] pointed out that third- and fifth-year medical students reported higher levels of anxiety due, mainly, to the fear of failing exam, lack of time for study and irrational thoughts about evaluations. Moreover, the anguish common to this period can trigger an increase in drug use. In addition, other authors mentioned in their studies that there is a direct relation between academic stress levels and substance abuse [18,23].

\section{Substance use/abuse by students during the exam period}

Despite the indisputable relevance of understanding the nature of stress in students, as well as studying intervention measures, the scarcity of literature regarding the exam period is noticeably clear.

Benzodiazepines was the group of substances with the greatest variation of use patterns during this period, with 48 participants (50\%) reporting increased frequency $(\mathrm{P}=0.02)$ and $39(41 \%)$, increased amount of use.

However, its use is not necessarily linked to the concentration improvement, since only five participants reported such reason to use. On other hand, 57 students (54.3\%) reported 'stress relief' using the substance and $69(65.7 \%)$ reported use for 'sleepiness induction or maintenance,', reinforcing the idea of increased levels of stress and dissatisfaction, in addition to loss or abdication of sleep quality in favor of longer preparation time for evaluations. When looking in the literature for data that could corroborate ours, we found only one Indian study published almost a decade ago, which approached academic stress during the exam period. The survey showed dissatisfaction with the university assessment system for $149(70 \%)$ academics [24]. 
Alcohol was the fourth with the lowest increase in amount of use and third with the smallest variation on the frequency of use. Among the affirmative answers for alcohol use, 151 responses pointed out 'stress relief' as the reason for it, being the third most common reason for use, which relates to Paduani's findings, where the participants indicated the post-test period as the second most favorable situation for alcohol use $(\mathrm{n}=36,11.7 \%)$ and parties and confraternization as the first one ( $\mathrm{n}$ $=220,72.5 \%)$. These data are also in agreement with ours, since 387 (78.2\%) alcohol users reported use for 'recreation' and 384 (77.6\%), for 'socialization'. The fact that only seven participants associate alcohol with improving concentration emphasizes its direct relation to the reduction of stress levels, instead of improving academic performance.

A group of substances often related to maintaining or improving academic performance in the literature is the stimulants, especially amphetamines. This purpose of use does not only affect medical students, as shown by a study with 4580 participants from various undergraduate courses [25]. The authors found that 382 students $(8.3 \%)$ used non-prescribed amphetamines, of which 249 (65.2\%) referred to 'improved concentration' as the main reason for use, and 228 (59.8\%) reported consumption to 'help to study'. In another research, involving 818 South African undergraduates, also not exclusively in medicine, the consumption of methylphenidate was considered significant. For 65 users (69\%), it happened only during the tests period. Among the users, $44(41 \%)$ said that used amphetamine to 'improve concentration'[26]. When compared to our study, it is crucial the understanding of use as a factor of 'concentration improvement', given that $66(41.3 \%)$ amphetamine's users reported this as a reason for consumption. In the exam period, the increase in the pattern of use was reported by 44 (30\%) and 37 (25.6\%) participants, for frequency and amount of use, respectively.

After understanding the relation between substance use, stress and the exam period, the variation in the pattern found in our study can be considered expected, in such a way that all nine substances had reports of consumption increase in frequency and amount of use during the evaluated academic interval. Despite the relevant findings, comparative analysis of our results was not possible due to the scarce specific literature at the time of the study.

However, it is necessary to emphasize that substance abuse is not a problem with an end. Lima, et al. [27] explored the different faces of the problem, showing that, more than a biological understanding, a social approach is necessary. In addition, the use of substances prevents the individual from seeking other coping or relief stress methods, since its use, especially marijuana, is related to pleasure. That said, the impact of use on a stressed individual is evident. According to Mondardo, et al. [28] academics who are in a period of anxiety and subjected to high levels of stress have problems in sedimentation and evoking the learned information.

\section{Conclusion}

Given the wealth of obtained data, our reflection could go beyond that just analyze the use of substances by medical students as a stress relief factor during the exam period.

Is clear that higher education involves a period of changes and new experiences in the student's life, which is corroborated by the clear increase in substance use after entering college in all groups analyzed. Among those surveyed, all showed an increase in the frequency and amount of use, with statistically significant values for marijuana and benzodiazepines.
Another noticeable relation in this study was between the reasons for consumption and the choice of the substance, such as, for example, "stress relief and alcohol", "improvement in sleep quality and benzodiazepines" and "improvement in academic performance and amphetamines".

Finally, despite the available literature, there is a clear gap in research that focuses on specific situations, as in this case, the exam period. Thus, we believe that the study can assist in the elaboration of strategies not only to contain and control the misuse of substances but also to improve the quality of life and reduce stress levels among academics during such a delicate period of graduation. Obtaining the profile of students in relation to substance use during exam is an important first step towards change.

\section{Contributorship}

Angelo Ap. de Barros Jr and Ulisses H. de Souza contributed equally as first authors since the conception and design of the study, analysis, data interpretation and writing of the manuscript. Tânia Zaleski was responsible for carrying out the statistical analyzes. Luiza Tatiana Forte contributed with the final review of the text. Francelise Bridi Cavassin contributed to the whole process, from the conception of the study to the analysis of the data, revision and construction of the manuscript.

\section{Acknowledgements}

None.

\section{Funding information}

None.

\section{Competing interests}

None.

\section{References}

1. Clark LA, Cuthbert B, Lewis-Fernández R, Narrow WE, Reed GM (2017) Three Approaches to Understanding and Classifying Mental Disorder: ICD-11, DSM-5, and the National Institute of Mental Health's Research Domain Criteria (RDoC). Psychol Sci Public Interest 18:72-145. [Crossref]

2. Global Burden of Disease Results Tool (2019) Institute for Health Metrics and Evaluation (IHME). Global Burden of Disease Collaborative Network.

3. Pacheco JPG, Giacomin HT, Tam WW, Ribeiro TB, Arab C, et al. (2017) Mental health problems among medical students in Brazil: A systematic review and meta-analysis. Rev Bras Psiquiatr 39: 369-378.

4. Coentre R, Góis C (2018) Suicidal ideation in medical students: Recent insights. Adv Med Educ Pract 9: 873-880. [Crossref]

5. Santa N Della, Cantilino A (2016) Suicídio entre Médicos e Estudantes de Medicina: Revisão de Literatura. Rev Bras Educ Med 40: 772-780.

6. Manejo do risco de suicídio (2018) British Medical Association.

7. Rotenstein LS, Ramos MA, Torre M, Bradley Segal J, Peluso MJ, et al. 2016 Prevalence of depression, depressive symptoms, and suicidal ideation among medical students a systematic review and meta-analysis. JAMA 316: 2214-2236. [Crossref]

8. Machado CS, Moura TM, Almeida RJ (2015) Estudantes de Medicina e as Drogas: Evidências de um Grave Problema TT - Medical Students and Drugs: Evidences of a Serious Problem. Rev Bras Educ Med 39: 159-167.

9. Paduani GF, Barbosa G de A, Morais JCR de, Pereira JCP, Almeida MF, et al (2008) Consumo de álcool e fumo entre os estudantes da Faculdade de Medicina da Universidade Federal de Uberlândia. Rev Bras Educ Med 32: 66-74.

10. Fontenelles MJ, Simões MG, Farias SH, Fontenelles RGS (2009) Metodologia da pesquisa científica: Diretrizes para elaboração de um protocolo de pesquisa. Rev Pará Med 23(3). 
11. Ayala EE, Roseman D, Winseman JS, Mason HRC (2017) Prevalence, perceptions, and consequences of substance use in medical students. Med Educ Online 22: 1392824 [Crossref]

12. Bogowicz P, Ferguson J, Gilvarry E, Kamali F, Kaner E, et al. (2018) Alcohol and other substance use among medical and law students at a UK university: A cross-sectional questionnaire survey. Postgrad Med J 94: 131-136. [Crossref]

13. Boniatti MM, Zubaran C, Panarotto D, Delazeri GJ, Tirello JL, et al. (2007) The use of psychoactive substances among medical students in southern Brazil. Drug Alcohol Rev 26: 279-285. [Crossref]

14. Schepis TS, Teter CJ, McCabe SE (2018) Prescription drug use, misuse and related substance use disorder symptoms vary by educational status and ttainment in U.S. adolescents and young adults. Drug Alcohol Depend 189: 172-177. [Crossref]

15. DeSantis A, Webb EM, Noar SM (2008) Illicit use of prescription ADHD medications on a college campus: A multimethodological approach. J Am Coll Heal 57: 315-324. [Crossref]

16. Oliveira LG, Barroso LP, Wagner GA, Ponce JC, Malbergier A, et al. (2009) Drug consumption among medical students in São Paulo, Brazil: Influences of gender and academic year. Braz J Psychiatry 31: 227-239. [Crossref]

17. Sáez MN, Medina V, Romaguera F, Ruza EC, Rodríguez A (2009) Factores de riesgo y propuestas para la reducción de la demanda de drogas en estudiantes de medicina de una universidad venezolana. SMAD - Rev Eletrônica Saúde Ment Álcool e Drog 5: 1-16.

18. Candido FJ, Souza R, Stumpf MA, Fernandes LG, Veiga R, et al. (2018) The use of drugs and medical students: A literature review. Rev Assoc Med Bras 64: 462-468.

19. Moutinho ILD, Maddalena NCP, Roland RK, Lucchetti ALG, Tibiriçá SHC, et al. (2017) Depression, stress and anxiety in medical students: A cross-sectional comparison between students from different semesters. Rev Assoc Med Bras 63: 21-28. [Crossref]
20. Almojali AI, Almalki SA, Alothman AS, Masuadi EM, Alaqeel MK (2017) The prevalence and association of stress with sleep quality among medical students medical students. J Epidemiol Glob Health 7:169-174. [Crossref]

21. Estrela YCA, Rezende ACC, Guedes AF, Pereira CO, Sousa MNA (2018) Estresse e correlatos com características de saúde e sociodemográficas de estudantes de medicina. CES Med 32: 215-225.

22. Guraya SY, Guraya SS, Habib F, AlQuiliti KW, Khoshhal KI (2018) Medical students perception of test anxiety triggered by different assessment modalities. Med Teach 40: S49-S55. [Crossref]

23. Hankir AK, Northall A, Zaman R (2014) Stigma and mental health challenges in medical students. BMJ Case Reports 2014: 205-226. [Crossref]

24. Nandi M, Hazra A, Sarkar S, Mondal R, Ghosal MK (2012) Stress and its risk factor in medical students: An observational study from a medical college in India. Indian $J$ Med Sci 66: 1-12. [Crossref]

25. Teter CJ, McCabe SE, LaGrange K, Cranford JA, Boyd CJ (2006) Illicit use of specific prescription stimulants among college students: Prevalence, motives, and routes of administration. Pharmacotherapy 26:1501-1510. [Pubmed]

26. Steyn F (2016) Methylphenidate use and poly-substance use among undergraduate students attending a South African university. S Afr J Psychiatr 22: 760. [Crossref]

27. Lima EH (2013) Educação em saúde e uso de drogas: Um estudo acerca da representação das drogas para jovens em cumprimento de medidas educativas. Fundação Oswaldo Cruz, MG: Centro de Pesquisas René Rachou.

28. Mondardo AH, Pedon EA (2005) Estresse e desempenho acadêmico em estudantes universitários. Rev Ciências Humanas 6: 159-180.

Copyright: $(2021 \mathrm{Ap}$ de Barros A. This is an open-access article distributed under the terms of the Creative Commons Attribution License, which permits unrestricted use, distribution, and reproduction in any medium, provided the original author and source are credited. 